研究課題別評価

1 研究課題名:

不飽和炭化水素を活用する精密有機合成

2 研究者氏名:中村正治

研究員:梁 春根（研究期間 H.16.6〜H.17.3）

3 研究のねらい:

手に入りやすい簡単な分子から, 複雑な構造の有用分子を作り出すことは合成化学の基本です. 本課題で はエチレン・アセチレン類などの有機工業化学の基本的な原料を, 精密有機合成に直接活用する新規の分 子変換プロセスの開発を目指しています. 新たな有機金属活性種を創り出すことによって, これらの不飽和炭 化水素類を用いる効率的な結合生成反応を見いだし, 究極的には貴重な化石資源の有効利用に新しい道を 拓くことを目標に研究を進めてきました。

4 研究成果:

人類の繁栄の確固たる物質基盤の確立のためには, エネルギー資源のみならず化学資源の開発, 活用が 必須である. 現在の化学工業の発展は化石資源, 特に石油の大量消費に基づくものであり, 次代の化学工業 の在り方を考えると, 現行の化学プロセスの革新が急務であることに疑いを容れる余地は無い. このことは. 既 存の反応触媒の高効率化の追求などは必ずしも抜本的な解決策を与えるものでは無く, むしろ「化学資源活 用」のコンセプトに基づいた全く新規な分子変換の設計, 開発が必要であることを意味する. 従前の有機合成 化学, とくに分子骨格の構築に重要な炭素一炭素結合生成反応には, カルボニル化合物などの極性化合物 が目的とする反応の足がかりとして広く用いられている. これらの極性化合物は石油化学工業の第一次化成 品であるエチレン等の無極性化合物から多段階工程を経て合成される物質群であり, もしこの後者を足がかり とする精密炭素一炭素結合生成反応が可能となれば, 化学工業におけるパラダイムシフトの第一歩となろう.

しかしながら,このような合成プロセスの革新は決して容易なことではない. エチレンや $\alpha$ オレフィン類を基質 とする精密制御された炭素骨格構築法自体が存在しないためである.このような背景のもと, 我々はさきがけ 研究において,これらの「炭素源」を活用するあたらしい合成反応の開発といら基礎研究に取り組んできた.こ れまでにない有機金属活性種や触媒反応を発見することによって, 当初期待していた以上の成果を現在まで に挙げている. これらの成果について以下紹介する.

\title{
1. エチレン類を用いる光学活性化合物の高選规的合成反忘開発
}

エチレンのような第一次工業産物を, 光学活性有機物のような高付加価值化合物の骨格形成反応に利用寸 る反応は, 選択性, 収率の面からこれまでまったく成功例が無かった. 我々は下図に示寸光学活性な亜鉛工 ナミドという有機金属活性種を創出することにより, 医農薬中間体としての重要性の高い光学活性なカルボニ ル化合物群の合成が, 極めて高い選択性と化学収率で可能となることを見いだした.
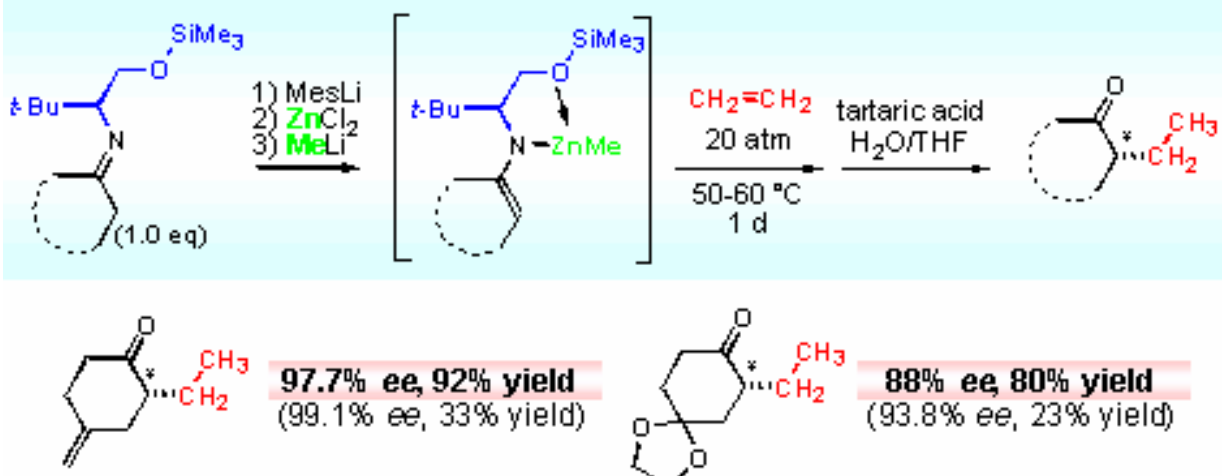

97.7\% ee, 92\% yield $(99.1 \% €, 33 \%$ yield)<smiles>CCC1CC2(CCC1=O)OCCO2</smiles>

$88 \%$ ee, 80\% yield (93.8\% ee, $23 \%$ yield)<smiles>CCC1CCCCCC1=O</smiles>

$95.6 \%$ ee, $82 \%$ yield<smiles>CCC1CC=CCCC1=O</smiles>

$96.4 \%$ ee, $93 \%$ yield 
2. イオレフイン類を孷素源とするケトン類の新規アルキル化反応の開発.

前述のエチレンへの付加反応に関して, 量子化学計算を用いた反応機構の精査を行ったところ下図にし めすように, 亜鉛エナミド基質とエチレンの軌道相互作用による活性化エネルギーの低下を鍵としてこの新 規炭素一炭素結合精製反応が進行していることがありきらかとなった(下図).

\section{D model of transition structure}

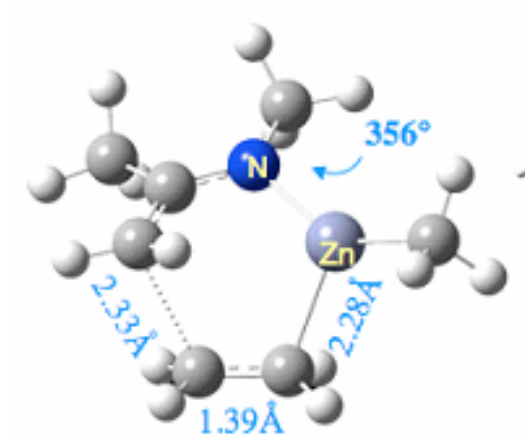

bond forming orbital interactions
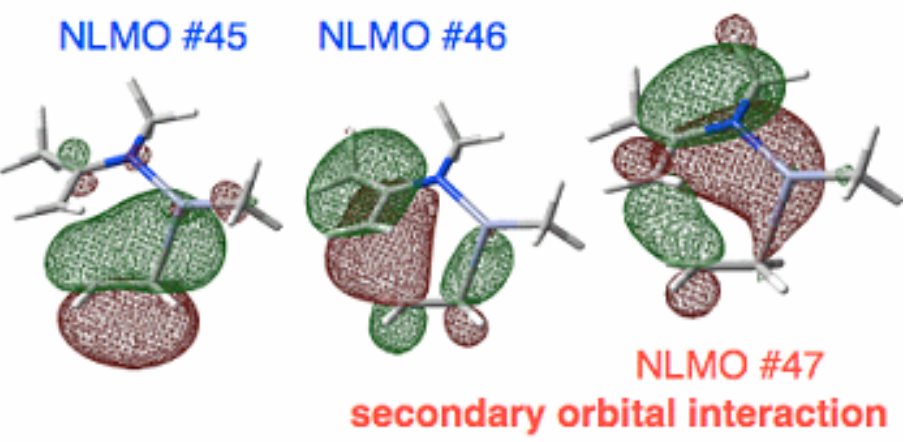

Natural Localized Molecular Orbitals (B3LYP/6-31+G*, Ahlrichs' SVP for Zn) GAUSSIAN 03

この知見に基づき更に亜鉛上の置換基を工夫寸ることによって, 多種多様な $\alpha$ オレフインによる $\alpha$ 位アル キル化反応が可能であることを最近見いだし，単純アルケンによる精密炭素骨格合成法の大きな可能性を 示すことができた。

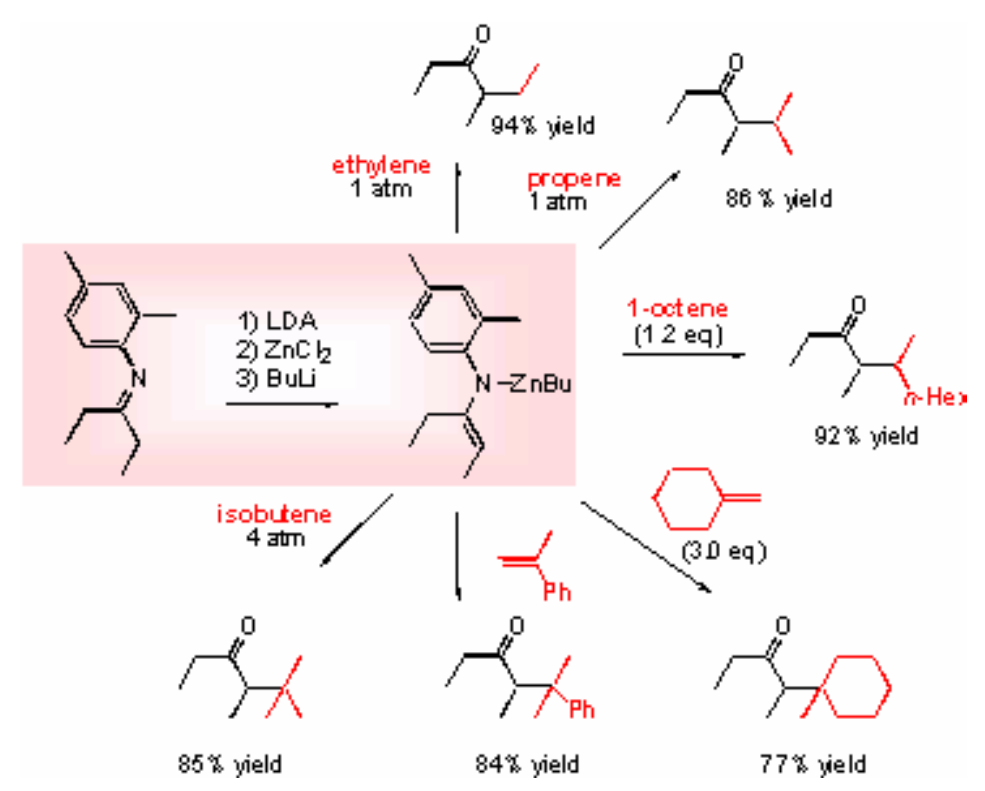

3.アセチレン類を用いる触媒的炭素骨格構築反忘の開発

アセチレンは石油資源に依存しない炭素源の一つであり, 歴史的にも化学工業との係りの深い化合物であ るが, 高度に制御された炭素骨格構築法への利用法の開発は進んでいないのが現状である. 我々は次項 に述べるようにエチレンの非極性炭素一炭素二重結合の金属による活性化に基づく炭素一炭素結合の生 成反応の検討を行なっている中で, インジウム塩を触媒とすることである種のカルボニル化合物がアルキン 類に触媒的に高収率で付加し効率的な炭素骨格構築法となることを発見した. 従前のアルキンの化学で は, 酸素や窒素などのへテロ元素化合物の付加や有機金属化合物の化学量論的な付加反応のみが有効 な化学変換であったため, この新規触媒反応はアルキン類の合成化学的利用に新しい道を拓くものであ る.

下図にしめすようにケトエステル類とアルキンとの等量混合物に, トリフルオロメタンスルホン酸インジウムを 触媒として加え, 加熱擋拌することで定量的に生成物を得ることが可能となる. ここで得られる生成物は, 医 農薬などの生理活性物質合成の中間体としての利用が可能であるが，同様な化合物を従来法で合成する ためには, 多段階工程と生成物の数 10 倍程度の廃溶媒や副生成物が発生する. これに対し本触媒反応 
は, 単工程, 触媒量の金属塩, 無溶媒, 低エネルギー, で進行するなどの利点に加え, まったく副生成物 を生じないといら特徵もある. 多様な官能基が存在する場合も反応は円滑に進行し, 対応するアルケニル 化生成物を良好な収率で与える極めて応用性の高い炭素一炭素結合生成反応であることが明らかとなっ た.

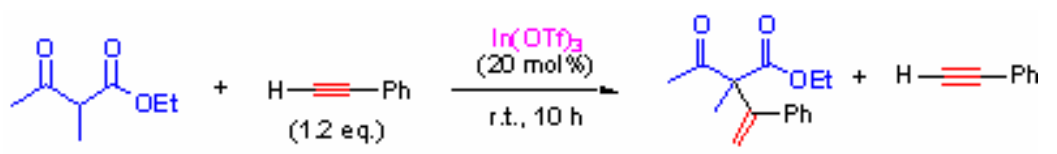

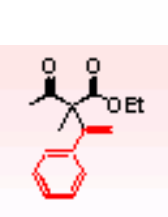

$99 \%$

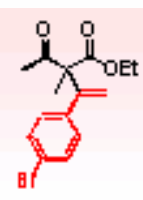

$97 \%$

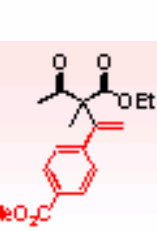

$97 \%$
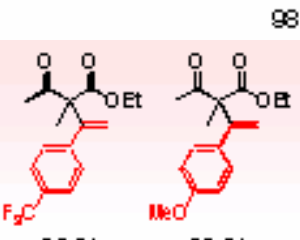

Q8

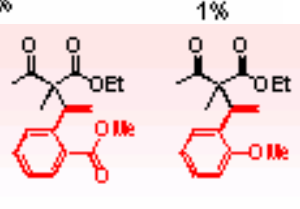

$92 \%$

$99 \%$
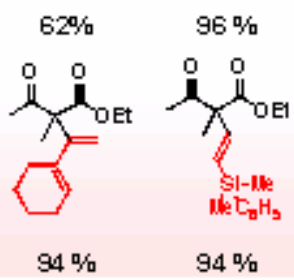

$99 \%$

$79 \%$

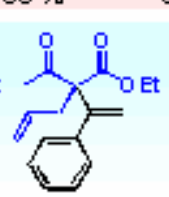

$90 \%$

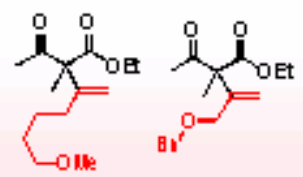

$80 \%$

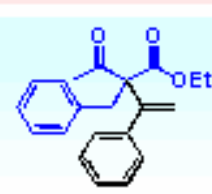

$93 \%$

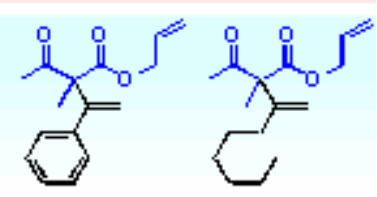

$93 \%$

$86 \%$

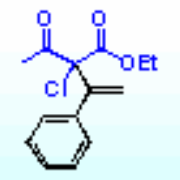

$93 \%$

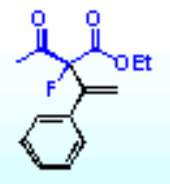

$89 \%$

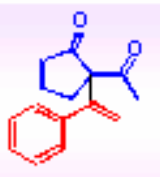

$94 \%$

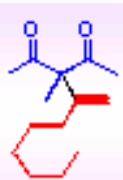

77 吅

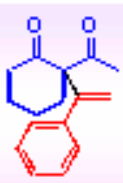

$85 \%$

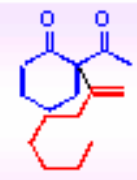

$82 \%$

最近アセチレンを用いる汎用性の高い直接ビニル化反応の開発にも成功した. 下図には一例としてモレキ ユラーシブによる触媒の活性化の例を示したが, 他にもアルミナやシリカゲルの様な細孔担体の存在下反 応が円滑に進行することを見いだしている.これはこれら担体表面を微細加工することによって反応場をナ ノスケールで制御する手法が有効に働くことを期待させる結果である.

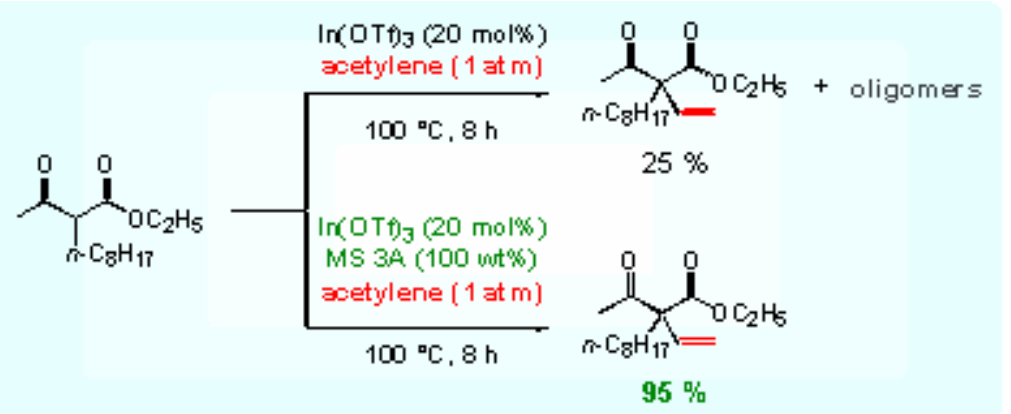

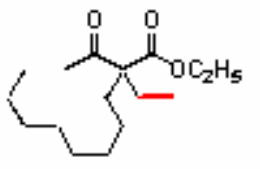

$95 \%$

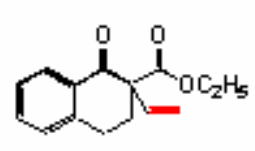

$100 \%$

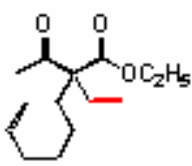

$93 \%$

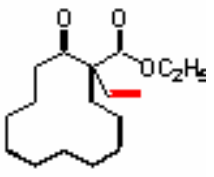

$98 \%$

同インジウム触媒系を共役ジイン類への $\beta$ ジカルボニル化合物への付加反応へと応用することで, 共役エ ンイン類の新しい位置選択的な合成法へと展開することが可能であることを見いだした. 本反応では, 原理 的に生成可能な $4 つ の$ 位置異性体のうち, たつた一つだけが選択的に, かつ高収率で生成する興味深い 炭素一炭素結合生成反応である. ここで得られたエンイン化合物はさらに既知反応であるパラジウム触媒に よるベンズアニュレーション反応を速やかに受け, もう一分子の共役ジインあるいはエンイン化合物と交差 
付加環化反応による多置換芳香族化合物を高収率で与えることが判明した. 同反応は見方を変えるとカル ボニル基質の $\alpha$ 位に芳香環を導入する新手法であり, 既存の芳香環導入法では不可能であった複雑な官 能基を有する他置換芳香環を効率よく導入できるユニークな合成反応となった.
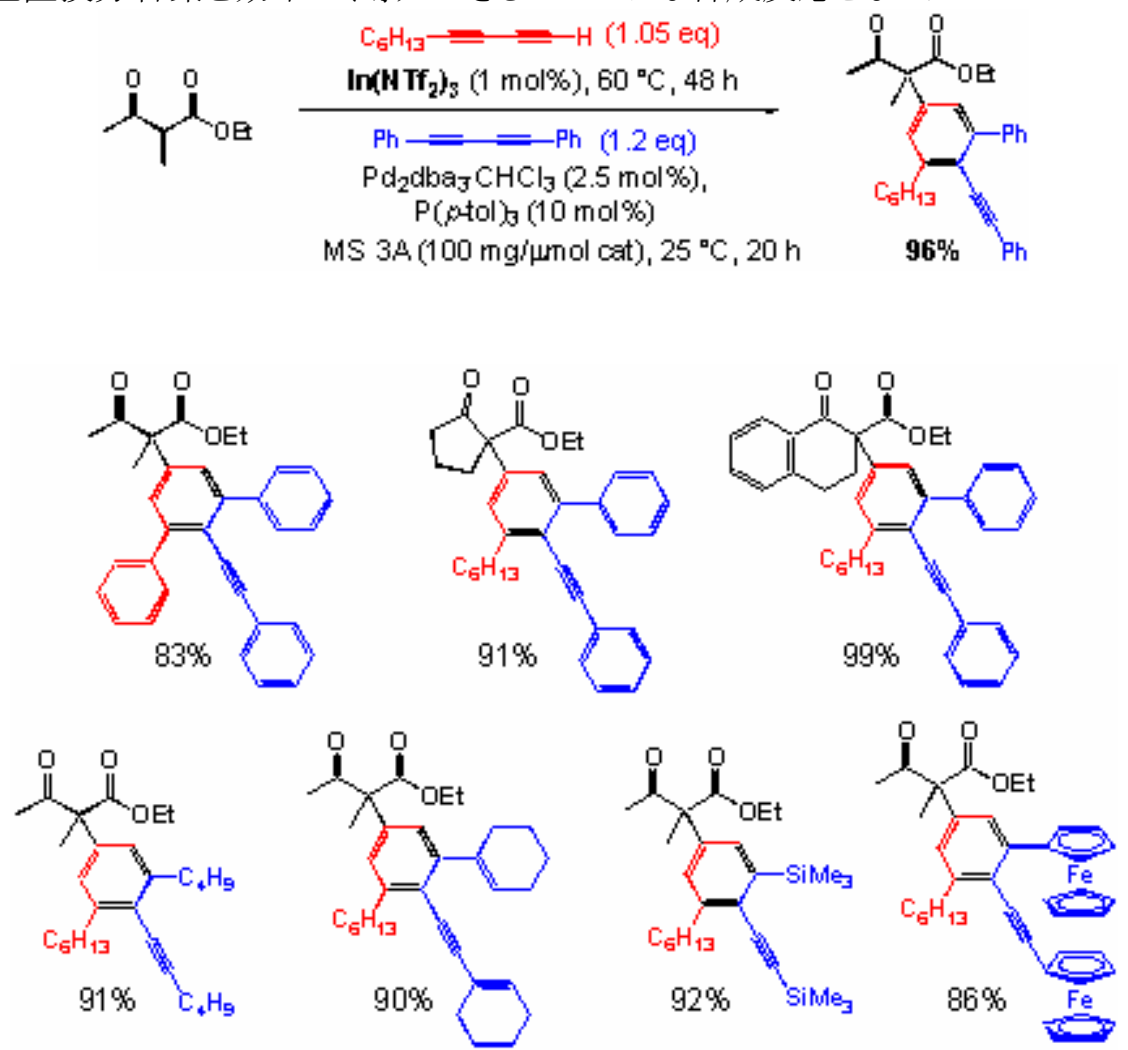

\section{4. 鉄触媒を用いる選択的炭素一炭素結合形成反応の開発}

これまで触媒的な精密合成反応では, 注目をされることの無かった鉄触媒に注目し新規炭素骨格構築手 法の開発を行なった. パラジウムやロジウムに代表される貴金属触媒が化学資源として地理的, 経済的, 政治的な制限が大きい現実を踏まえると,これらの貴金属触媒を鉄などの卑金属触媒に置換することは興 味深いテーマでもある.さらにこれまで未開拓の反応性の発見に遭遇することも想像に難くない. 事実われ われは研究の過程で下図に示すように, 鉄触媒がこれまでの金属触媒には不可能であった化学変換を可 能とすることを見いだした.

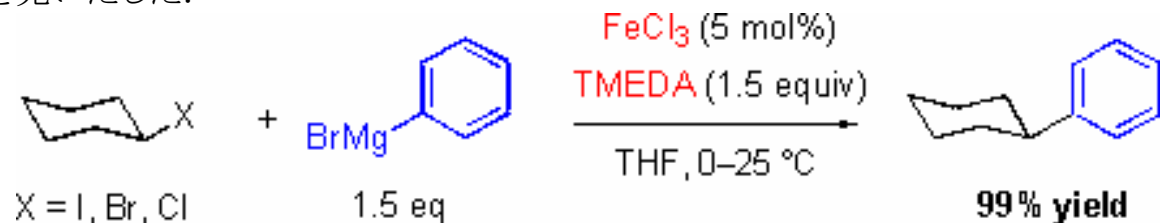

本反応の発見によって, 種々の有機金属試薬と八ロゲン化アルキルの効率的なカップリング反応に, 安全 性，経済性に優れる鉄を触媒とすることが可能となった。更に最近上式の有機マグネシウム化合物を有機 亜鉛化合物へと変えることで種々の官能基を有する基質同士の結合反応を達成した. これによって糖誘導 体の複雑分子の高効率骨格延長などが可能となり, 興味深い複雑分子群の合成に活路が拓かれた.
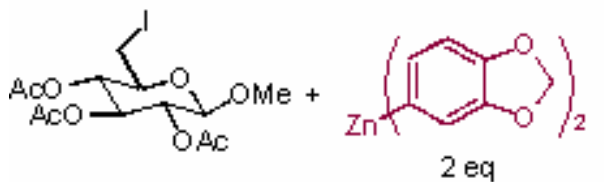

2 eq

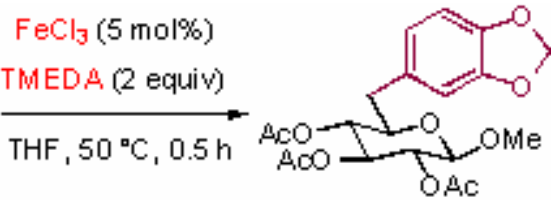

$90 \%$ yield

5 自己評価:

研究期間中にエチレンやアセチレンなど活性化されていない $\pi$ 電子系に対して効率的に付加反応を 起こす炭素ユニットの探索を続けてきた.この結果, 独自に設計創出した有機亜鉛試薬や有機インジウ ム試薬が, 求め続けた新反応を効率的に起こすことを見いだし, さらには効率の良い炭素一炭素結合形 成反応へと応用することが出来た. これらの成果は, 本研究の目標であった, 不飽和炭化水素類, 特に, 
オレフイン類やアセチレン化合物を直接活用する精密合成反応が可能であるということを示すと同時に, 既存のカルボニル化合物やハロゲン化アルキルなどの求電子的な化合物を出発原料とした合成経路で は困難であった化合物群の合成に有効であることを示すことが出来た. その一方でこれら単純有機分子 を出発原料とした場合, 最終生成物に求められる「構造的な複雑さ」を効率的に実現する為には, まだ まだ方法論として未成熟であり, 単工程多段階結合生成反応などへの応用研究が必要であることを痛 感した. 当初本課題研究の主旨であった未活用炭素資源の有効利用の為の新反応開発という考え方 は, 時流をさきがけたものであったことは, 当該研究最終年度の平成 17 年度から京大丸岡教授を代表と した文部科学省特定領域研究が開始されていることからも確認できよう. また, 本研究期間中に, 鉄を触 媒とする新規クロスカップリング反応を開発することができた.これは上述の炭素資源の活用といら概念 に対し，金属資源の活用といら概念であるといえる. 本さきがけ研究を通して，これら化学資源の活用を 新反応開発の指針として展開できたことは, 特許や論文・学会発表以上に大きな成果ではなかったかと 感じている.

6 研究総括の見解:

単純な原料から、高負荷価値型変換を行うことを念頭におき、アルケンやアルキンといった非極性型出 発物質も使える新反応を見出した。さらに、助剂として用いる金属種をどこにでもあるありふれた鉄など を含む触媒系を開発した。高分子反応への適用の可能性や、液晶分子の効率的な新合成法を考案す るなど高く評価される成果を挙げている。

7 主な論文等：

[1] "Indium-Catalyzed Addition of Active Methylene Compounds to 1-Alkynes" Nakamura, M.; Endo, K.; Nakamura, E. J. Am. Chem. Soc. 2003, 125, 13002-13003.

[2] "Iron-Catalyzed Cross-Coupling of Primary and Secondary Alkyl halide with Aryl Grignard Reagents" Nakamura, M.; Matsuo, K.; Ito, S.; Nakamura E. J. Am. Chem. Soc. 2004, 126, 3686-3687.

[3] " $\alpha$-Alkylation of Ketones by Addition of Zinc Enamides to Unactivated Olefins", Nakamura, M.; Hatakeyama, T.; Nakamura, E. J. Am. Chem. Soc. 2004, 126, 11820-11825.

[4] "Alkylation of Magnesium Enamide with Alkyl Chlorides and Fluorides" Hatakeyama, T.; Ito, S.; Nakamura, M.; Nakamura, E. J. Am. Chem. Soc. 2005, 127, 14192-14193.

[5] "3-Zinciobenzofuran and Indole: Versatile Tools for Constuction of Conjugated Structures Containing Multiple Benzoheterole Units" Nakamura, M.; Ilies, L.; Otsubo, S.; Nakamura, E." Angew. Chem. Int. Ed. 2006, 45, 944-947.

特許 (6件)

[1]

発明者: 中村正治·遠藤㥀平·中村栄一

発明の名称:「カルボニル化合物の触媒的 $\alpha$ 位アルケニル化法による新規オレフイン類の合成」

(特願 2003-333802)

出願人: 科学技術振興機構

[2]

発明者: 中村正治·宮崎壮宏·中村栄一

発明の名称:「カルボニル化合物の製造方法」(特願 2004-39078)

出願人: 科学技術振興機構

[3]

発明者: 中村正治·松尾敬子·伊藤慎庫·中村栄一

発明の名称:「芳香族化合物の製造方法」(特願 2004-33941)

出願人: 科学技術振興機構

[4]

発明者: 中村正治·高瀬俊和·江口恵二

発明の名称:「低温フロー迅速インジェクション NMR (Cold Flow Rapid Injection for NMR)」 
（特願 2004-224663）

出願人: 科学技術振興機構

[5]

発明者: 中村正治·松尾敬子·伊藤慎庫·中村栄一

発明の名称:「芳香族化合物の製造方法」(特願 2004-282578)

出願人:科学技術振興機構

受賞 (2件)

2005 年 11 月 Banyu Young Chemist Award

2005 年 12 月有機合成化学協会研究企画賞

招待講演 (1件)

2005 年 7 月 The 13th IUPAC International Symposium on Organometallic Chemistry Directed Towards Organic Synthesis (OMCOS 13) (Geneva, Switzerland) 